\author{
Anna Birketveit \\ Western Norway University of Applied Sciences \\ Hege Emma Rimmereide \\ Western Norway University of Applied Sciences \\ Monika Bader \\ Western Norway University of Applied Sciences \\ Linda Fisher \\ University of Cambridge
}

DOI: http://dx.doi.org/10.5617/adno.5643

\title{
Extensive reading in primary school EFL
}

\begin{abstract}
Reading in the English subject in both primary and secondary school often involves studying course book texts in detail. Therefore, pupils are rarely exposed to longer texts which require reading for meaning, a skill needed in higher education and working life. With the right reading material, extensive reading (ER) should start already in primary school.

This article reports on a study of primary school pupils from three different schools and their perceptions of an extensive reading and writing project, as well as their responses to the reading material offered. The study was designed to address the following research questions:

1. Which types of reading material appeal to the pupils in the study?

2. What is the role of gender in the pupils' evaluation of the reading material?

3. Are there differences between the pupils' evaluation of the reading material offered, depending on their previous academic achievement?

4. What are the pupils' attitudes towards (extensive) reading?

Two sets of questionnaire data were collected in the course of the project. First, during the reading, the learners were asked to answer a questionnaire about each book they had read or attempted to read. At the end of the project, the learners were asked to complete a questionnaire about their overall perception of the project.

The study shows that there was a significant difference between the schools in the evaluation of the reading material, and there was also a significant difference between boys and girls in the perception of the reading material. Moreover, the study shows that the learners valued the chance to select the reading material themselves highly. When carrying out ER with pupils, it is essential to be aware of gender differences in reading preferences and ensure that there are enough books to cater for both boys' and girls' particular interests. Moreover,
\end{abstract}


fostering a reading culture in both the Norwegian and English subjects is important.

Keywords: extensive reading, gender differences, choice of books, the importance of self-selection of books, motivation for reading

\section{Ekstensiv lesing i engelsk som fremmedspråk i barneskolen}

\section{Sammendrag}

Lesing i skolefaget engelsk i både barne- og ungdomsskolen betyr ofte at elevene må gjøre rede for larebokteksten på detaljnivå. Derfor møter elevene sjelden lengre tekster som krever forståelse av meningen med teksten, en ferdighet det forventes at de behersker i høyere utdannelse og i arbeidslivet. Med det rette utvalget av tekster burde elevene øve seg på ekstensiv lesing allerede i barneskolen.

Denne artikkelen legger frem resultater fra en studie av elever fra tre forskjellige barneskoler og deres oppfatninger av et ekstensivt lese- og skriveprosjekt i tillegg til deres respons på utvalget av tekster. Forskningsspørsmålene i studien er som følger:

1. Hvilke typer lesestoff appellerer til elevene i studien?

2. Hvilken betydning har kjønn i elevenes evaluering av lesestoffet?

3. Har elevenes tidligere akademiske resultater betydning for deres evaluering av lesestoffet?

4. Hvilke holdninger har elevene til ekstensiv lesing?

To typer spørreskjema-data ble samlet inn i løpet av prosjektet. Først, i løpet av leseperiodene, ble elevene bedt om å svare på et spørreskjema om hver bok de hadde lest eller prøvd å lese. Når prosjektet var avsluttet, ble elevene bedt om å fylle ut et spørreskjema om deres totale opplevelse av prosjektet.

Studien viser at det var en signifikant forskjell mellom skolene i elevenes vurdering av tekstene som ble tilbudt som lesestoff, og det var også en signifikant forskjell mellom gutter og jenter. Dessuten viser studien at elevene satte stor pris på muligheten til å velge lesestoff selv. Når man gjennomfører ekstensiv lesing med elever, er det viktig å vcere klar over kjønnsforskjeller $i$ elevenes lesepreferanser og forsikre seg om at utvalget av bøker er stort nok til å ivareta både gutters og jenters spesielle interesser. Dessuten er det viktig a utvikle en kultur for lesing i både norskfaget og engelskfaget.

Nøkkelord: ekstensiv lesing i engelsk, kjønnsforskjeller, elevers valg av bøker, betydningen av å velge bøker selv, motivasjon for lesing 


\section{Introduction}

If we accept that reading longer texts for meaning might be a useful skill in pupils' further education and later life, and that such reading also might provide a great deal of pleasure, then arguably more extensive reading (ER) should be introduced into the curriculum. Reading in the English subject in both primary and secondary school often involves studying course textbooks in detail, meaning that pupils are rarely exposed to longer texts (Charboneau, 2012). This study was designed to see whether, with the right materials (see list of suggested texts in appendix), extensive reading was feasible with primary-aged pupils (1112 year olds) in the Norwegian context, and what the pupils' perceptions of ER might be. Our focus here is on the choices pupils make when they select books, on their enjoyment of the reading experience, on how much reading they do, and we focus also on the pupils' gender and academic performance as possible significant variables.

Important characteristics of an extensive reading (ER) approach are that the learner reads a lot, reads for pleasure, and reads for overall meaning rather than detail. The learner should also have the choice of which texts to read, with a wide variety of reading material available. The readers read unassisted, and the reading is viewed as its own reward (Day \& Bamford, 1998).

Unusually, therefore, for a paper in a special edition on metacognition and reading, our focus is not on reading strategies that are necessarily "consciously selected by the learners" (Cohen, 1998, p. 4). Rather, we argue that there is justification in the area of language learning for allowing pupils to immerse themselves in books and make sense of them using a range of cognitive or metacognitive strategies that they are free to draw on from their own learning repertoires, for example, drawing on pictures as support, or focusing on cognates.

We argue that young learners are able to make their own way through such texts, developing their own problem-solving approaches, unsupported by the teacher, and that this is a not only a valuable life skill, but can improve motivation for reading and for language learning.

\section{Theoretical background}

\section{Extensive Reading and language learning}

An extensive reading approach where the reader is provided with rich, varied, useful and authentic language input, has proved beneficial for both first and second/foreign language learning. One of the strong proponents of ER, Stephen Krashen, hails ER as "one of the most powerful tools in language education" (Krashen, 2004, p. 1). Grabe (1991), discussing its benefits, states that "longer periods of silent reading build vocabulary and structural awareness, develop 
automaticity, enhance background knowledge, improve comprehension skills, and promote confidence and motivation" (Grabe, 1991, p. 396).

One of the most important studies of the effects of extensive reading on foreign-language learning was conducted by Elley and Mangubhai (1983). They found that students in extensive reading programmes made greater progress in their language skills than those following a more traditional teaching method. Subsequent studies offered further support for these findings, showing that extensive reading yields various linguistic gains (Al-Homoud \& Schmitt, 2009; Bell, 2001; Cho \& Krashen, 1994; Elley, 1991; Elley \& Mangubhai, 1983; Hafiz \& Tudor, 1989; Janopoulos, 1986). Furthermore, a pilot project on the effect of extensive reading of picture books and illustrated books carried out in a class of Norwegian 11-year-olds showed a clear improvement in L2 writing with regard to story building skills and length of texts (Birketveit \& Rimmereide, 2012, 2017).

In addition to increasing the overall competence in the target language, extensive reading has a potentially significant role to play in the affective dimension of the reading process. Reading in a second language is demanding and requires positive attitudes and reader motivation (Day \& Bamford, 1998; Dörnyei, 1998; Grabe, 2009). Day and Bamford's (1998) expectancy-value model of motivation outlines four variables that affect the reader's motivation to read in a second language: materials, attitudes, reading ability and sociocultural environment. In this model, "reading ability", which refers to the pupils' selfefficacy beliefs as regards their reading in the second language, and the sociocultural environment, which includes the influence of society, family and friends, are considered less significant; deficits in both can be compensated for by positive reading attitudes and appropriate materials. The reader's motivation is strongly affected by the material offered. For example, how interesting it is to the reader, how appropriate the linguistic level is, how attractive it is and very importantly, how accessible it is to the reader. Attitudes towards second language reading are equally significant, and can be viewed as having four sources: attitudes towards first language reading; previous second language reading experiences; attitudes toward the second language, culture and people; and the second language classroom environment (Day \& Bamford, 1998, p. 23). As Day and Bamford (1998, p. 26) point out, the impact of extensive reading on the last two sources can be substantial. This has been confirmed in a number of studies, including some already mentioned (Al-Homoud \& Schmitt, 2009; Bell, 2001; Birketveit \& Rimmereide, 2012, 2017; Cho \& Krashen, 1994; Elley, 1991; Hafiz \& Tudor, 1989; Janopoulos, 1986). What these studies show is that involvement in extensive reading programmes positively affects attitudes towards second language reading and encourages students to become eager readers.

Although research demonstrates the need for and effectiveness of ER (Drew, Oostdam, \& Van Toorenburg, 2007; Hellekjær, 2007), it is a rare approach both 
in Norway and elsewhere. According to Day and Bamford (1998, p. 41), extensive reading continues to be "the approach less taken", despite the overwhelming evidence of its importance. The reasons given for the lack of ER are many. ER requires teachers to assume a different role in the classroom, relinquishing some of their control and providing help if the learner requires it, something that teachers and students might find unsettling. Since an ER approach involves selfselection of reading material, the reading materials risk being labelled as "light". There is also confusion between class readers and extensive reading material. If class readers are used and everybody is forced to read the same book, the approach lacks the important factor of learner autonomy. The dominance of the reading skills approach in EFL also leaves little space for ER (Day and Bamford, 1998, p. 46). In this approach, skimming, scanning, top-down or bottom-up strategies are taught explicitly. Finally, there is the issue of costs and the work required to set up an extensive reading programme. School libraries often do not have sufficient selections of books in English to support extensive reading programmes.

In relation to availability of reading material, it must be acknowledged, though, that a lot of reading nowadays takes place on screen. Through reading of news, blogs and gaming, pupils read and often write extensively without it being recognized as valuable training in these basic skills. These days, many texts come in digital versions only (for example Sunday newspapers), or they come in both digital and paper versions. This opens up possibilities for digital reading in many fields and it has the potential to increase reader motivation. In the project that this study reports on, only printed stories were used, as the schools involved did not have the equipment needed to allow a whole class to read digitally. However, with the availability of computers increasing in schools and at home, there is a need to rethink the concept of reading to also include digital reading.

\section{Reading and gender}

There seem to be few studies on gender differences in reading in L2. Recent Norwegian national tests for years 5 and 8 show very little difference between boys' and girls' reading performance in English as L2 (UDIR, 2013). However, as discussed below, research has been carried out concerning gender differences in reading in L1 (Hoel, 2008; Roe, 2013; Wagemaker, Taube, Munck, Kontogiannopoulou-Polydorides, \& Martin, 1996).

Kverndokken (2013) gives an outline of research concerning gender differences in reading. He refers to the IEA research report Are girls better readers? Gender differences in reading literacy in 32 countries (Wagemaker et al., 1996). A closer examination among the 14-year-olds revealed that Norwegian boys performed better than girls in tasks related to non-cohesive texts, such as graphs, tables and diagrams. Girls performed better on tasks related to texts about humans or human activities or describing animals acting like humans. Girls outperformed boys also in reading narrative texts and long texts. 
Boys performed relatively better when the literary text had a male as the main character as opposed to a female main character, whereas this did not seem to matter to the girls. The PISA results in reading for 2000 and 2009 show that girls score considerably better than boys (Egelund, 2012) and PIRLS 2016 shows that gender differences in reading have increased from 2011 to 2016 in Norway as well as in other Nordic countries (Gabrielsen, 2017). The differences were greatest for cohesive texts and in texts requiring reflection.

PISA 2009 (Egelund, 2012; Gabrielsen, 2017) shows that girls spend a lot more of their spare time reading than boys do, and they read literary texts on a regular basis. Reading literature seems to have a positive impact on the reading tests. Boys however, tend to read newspapers, magazines and cartoons. When asked about their attitudes to reading, boys tend to see reading as something they have to do because it is useful.

Norwegian pupils' understanding and knowledge about reading strategies can be classified as average, but again Norwegian boys score lower than the girls and their peers internationally. They appear to be less good at distinguishing between useful and not-so-useful reading strategies for a given text.

According to Roe (2013), reading campaigns in school tend to offer literary narratives, and these give ample training in reading and reflection. However, the PISA texts are mainly factual texts. The number of weak readers among boys is twice as high as among girls. An expert group was established in 2011 in the EU to suggest measures to reduce the numbers of weak readers among boys and their suggestions comprise more digital reading in schools, adapting the reading material to the pupils' interests, and a greater choice of reading material for all pupils (European Commission, 2012).

According to Brozo (2006, p. 71),

We can start by taking the literary behavior and attitudes of male students more seriously and designing language curriculums that honor their unique imaginations. Boys have passions, hobbies, aspirations, and experiences rife with opportunities for genuine curricular links. Exploring these links and inviting male students to find connections between their lives and school-based literacy may be the key to reducing achievement disparities between them and their female peers.

Nasjonalt senter for leseopplæring og leseforskning, Universitetet i Stavanger (The Norwegian Reading Centre, The University of Stavanger) reports on research carried out (Hoel, 2008). In 2004, the Reading Centre interviewed 61 boys aged 11-17 about their reading habits and interests. The study revealed that the boys read because it was useful, but few of them saw themselves as readers. They conceived the term "reader" as a "reader of literature", whereas, for example, reading newspapers was not thought of as relevant to be called a reader. Furthermore, the schools seemed to be the most influential arena for suggesting reading material, and this raises the question: what would happen if the boys' wish to read useful material was properly taken into account? The 
boys suggested that more time for reading, two to three hours a week, was needed in school, and the pupils should be allowed to choose the reading material themselves. Furthermore, the study revealed that very many boys like humorous texts.

A study worth mentioning is Brevik (2016) who found that upper secondary school male students who were poor readers in their L1 were not necessarily poor readers in their L2. If they played computer games extensively in their spare time, they actually performed at a high level in more than $40 \%$ of the cases. Moreover, this is a strong argument for the importance of reader motivation in reading performance and language learning.

\section{Metacognition in EFL reading}

According to Bakken (2017), pedagogical understanding of EFL-reading, follows national and international school policies and political agendas. While the 1980s and 1990s emphasized pupils' exposure to different types of texts, the current national curriculum (LK06), in line with the Common European Framework of References (CEFR,) is competence driven. Therefore, while retaining the importance of exposure to different types of texts, LK06 also emphasizes strategies "suited to the objective". Thus, reading in EFL has a focus on "metaawareness" (Bakken, 2017, p. 13).

So when it comes to ER, what kind of reading strategies are we talking about? ER means to read for overall meaning. Good top-down reading strategies are required, but also the ability to stop and decode words that are essential for overall understanding. Furthermore, other useful strategies are predicting and anticipating what comes next, or sometimes going back in the text to verify or discard former conclusions. When reading extensively in EFL, the illustrations can be very helpful in extracting the overall meaning of the text. With some texts such as picture books, the pictures are as important as the verbal text, and only together can the full meaning be accessed. Thus, reading pictures and understanding the interaction between pictures and verbal text are part of reading strategies (Kolb, 2013).

Such reading strategies are not in themselves inherently metacognitive; it depends on the learners' awareness of whether or not they are using a strategy. Conscious strategy can become a process, i.e. metacognitive strategies can become cognitive and, in fact, the distinction between the two is hard to draw (Cohen, 1998). Essentially, it is likely that learners who are doing ER are employing communication strategies (reading for meaning), not learning strategies (Cohen, 1998).

\section{Extensive reading in primary school}

An important factor of successful reading programmes is that the reading material is accessible and pleasurable. Stories hold a special position as teaching material, especially high-interest stories with ample visual support. According to 
Egan (1997), narratives exist as a predisposition in the mind. They offer a way of structuring and making sense of things. Nursery rhymes and stories helped develop our first language, and have a large potential in L2 acquisition. As traditional course books tend to offer shorter texts and extracts of narratives rather than whole stories, there is a need for supplementing this teaching material (Birketveit \& Williams, 2013; Munden, 2014).

Another important factor is that the reading material has to cater for different reader interests and levels. The learner needs to be motivated to read. According to Reeve (2005), motivation is dependent on the needs for competence, relatedness and autonomy. Motivation is highest when the challenge is neither too easy nor too difficult, when there is support from your learning environment, and when the learner has a choice of what to learn and how it should be learnt. Thus, when carrying out extensive reading programmes, this implies that the learners should read self-selected stories and that there is a wide choice of reading material catering for different levels and interests. In the aforementioned pilot study (Birketveit \& Rimmereide, 2012), the learners were asked about their reading preferences, and the answers showed a wide variety in reading tastes and competence. Their preferences comprised picture books, books with funny/ scary pictures, books with illustrations, books without too many pictures, football books, crime stories, romantic stories, action stories, fantasy, simple/easy books, and long books.

\section{The aims of the study}

The study reports on primary school pupils' perception of an extensive reading (ER) and writing project and their response to the reading material offered, including a focus on the pupils' gender and academic achievement as variables. This is a large study, and the analysis of pupils' writing will be discussed in subsequent articles.

\section{Research questions}

This study was designed to address the following research questions:

1. Which types of reading material appeal to the pupils in the study?

2. What is the role of gender in the pupils' evaluation of the reading material?

3. Are there differences between the pupils' evaluation of the reading material offered, depending on their previous academic achievement?

4. What are the pupils' attitudes towards (extensive) reading? 


\section{Methods}

\section{Participants and procedure}

This study is part of a larger project investigating the effect of extensive reading on young language learners' writing skills. The present study concerns itself with the reading part of the project. It involves 83 Norwegian learners of English, aged 11-12, based in three different schools in a larger town in Norway. The schools were selected, first, on the basis of convenience as all three had collaborated with the researchers previously and had expressed an interest in the project. Secondly, the schools were selected as they fitted the criteria of pupil performance in the $5^{\text {th }}$ grade national tests in English. The results of the national tests are grouped into three levels of performance. Level 1 is the lowest level, level 2 is the average level and level 3 is the highest level. In the project, school 1 performed at level 1 in the national tests, school 2 was at level 2 and school 3 was at level 3. The schools from all three levels were chosen to investigate whether ER motivates and engages learners equally, no matter their performance in the national tests. In fact, as Elley and Mangubhai's (1983) longitudinal study in Fiji showed, the weakest performers benefited the most from the extensive reading programme.

The study was conducted over a period of 14 months in three classes, one in each school. While these classes were selected by the schools, again for convenience, the fact that there is an equal distribution of high and low performers between the classes in each school, means they are likely to be typical for that institution.

There were three reading cycles per class and each cycle involved a 4-week period of in-class extensive reading during English lessons, totalling eight lessons of 45 minutes each, or 90 minutes per week for four weeks. The classes could organize the length of the reading sessions as they wished, as long as they met the requirement of 90 minutes per week of extensive reading for four weeks during each cycle. In addition, the pupils could take the books home to read, although for practical purposes, it seemed they mostly read in school. Two sets of questionnaire data were collected in the course of the project, which will be presented and analysed in this article. First, during the reading, the learners were asked to answer a questionnaire about each book they had read or attempted to read. At the end of the project, the learners were asked to complete a questionnaire about their overall perception of the project.

\section{Material}

The pupils were able to choose books from a selection of at least three times as many books as there were pupils in the class. There were three different crates of books that circulated between the schools so that each new reading cycle had a new crate of books. By the third and last reading cycle, all pupils had had access to the same books during the project. As this was an extensive reading 
project in EFL, we wanted the learners to have support in illustrations. Thus, the texts varied from picture books proper (at least one picture per double-spread) to illustrated books. Table 1 shows the various types of books the pupils could choose.

Table 1. Types of books with examples in the extensive reading project

\begin{tabular}{|l|l|}
\hline Type of book & Example \\
\hline Picture books, humorous or other & Cole (1996) [1986]. Princess Smartypants. \\
\hline Comic superhero / adventure superhero & Hill (2009). Spider-man Versus the Vulture. \\
\hline Fairy tales with a twist / fairy tales & $\begin{array}{l}\text { Trivizas \& Oxenbury (1993). The Three Little Wolves } \\
\text { and the Big Bad Pig. }\end{array}$ \\
\hline Science fiction & $\begin{array}{l}\text { Kotzwinkle (2002). E. T. The Extra-Terrestrial. The } \\
\text { Book of the Green Planet. }\end{array}$ \\
\hline Real events & Driscoll (2012). Titanic: The Story Lives On! \\
\hline Real life stories & Wilson (1999). The Illustrated Mum. \\
\hline Animals & $\begin{array}{l}\text { Vindalen. (1993). Bert the Beaver, and (1993). Ossy the } \\
\text { Ostrich. }\end{array}$ \\
\hline Classic stories & Sebag-Montefiore (2010). Wuthering Heights. \\
\hline Legends & Austin (2008). Robin Hood. \\
\hline Tall tale inspired (exaggerations) & $\begin{array}{l}\text { Dahl (1983). The Witches. } \\
\text { Walliams (2012). Ratburger. }\end{array}$ \\
\hline Graphic novels & $\begin{array}{l}\text { Kinney (2007). Diary of a Wimpy Kid. } \\
\text { Pichon (2011). The Brilliant World of Tom Gates. }\end{array}$ \\
\hline Adapted texts & $\begin{array}{l}\text { In the Usborne Young Reading series: Pride and } \\
\text { Prejudice, The Three Musketeers, Robin Hood, } \\
\text { Spartacus, King Arthur, Robinson Crusoe. }\end{array}$ \\
\hline
\end{tabular}

\section{The questionnaires}

\section{Questionnaire answered during the reading cycles}

Each learner, identified by an id number, answered a questionnaire after each book they had read or attempted to read. They were asked to indicate the title of the book, and if they had finished the book, they gave it an evaluation, where the three possible categories were "good", "fairly good" or "poor". If they had not finished the book, they were asked to state why, and again three categories were possible: because it was "too difficult", "too boring” or "another reason". They were not asked to explain what "another reason" was. The study can be said to have a high internal validity because of the stability of the test group and high levels of pupil response. The first questionnaire where the pupils evaluated the books they read or attempted to read, was used repeatedly in all three reading cycles, totalling 948 answers.

\section{Questionnaire answered after finishing the project}

The questionnaire conducted after the completion of the project was designed to assess pupils' experience of the reading and writing project, particularly probing their attitudes and motivation for reading. Some of the questions ask for pupils' values and attitudes, motivation, understanding and knowledge after the project, whereas some of the questions required the pupils to reflect on the changes in 
their perceptions and attitudes. The results from the questionnaire are based on the pupils' self-reporting through the questionnaire. As before, using the assigned code, unknown to the researchers, 78 pupils out of 83 answered the questionnaire.

This had four different types of questions, most of which (14 in total) were closed questions, phrased as a statement to which the pupils had to give one response. Most of the closed questions (12 in total) were about reading and two questions were about writing. In one of the questions, the pupils could give multiple answers, one question was a yes/no question and six questions were open and allowed free and voluntary response. In the closed questions, the questionnaire allowed four options, which were "Agree strongly", "Agree”, "Disagree" and "Disagree strongly". The pupils were not given the option of "Neither agree nor disagree".

\section{Statistics}

Evaluation of finished books and reasons for not finishing books were treated as categorical variables in the statistical analysis. Comparison of these variables between schools and between genders was performed by Pearson chi-square test. IBM SPSS Statistics version 22 was used for the analyses, and the level of significance was set to 0.05 .

\section{Ethics}

The project was approved by the Norwegian Social Science Data Services (NSD). Consent forms were collected from the participants and their parents. Each participant was given an id number to ensure anonymity.

\section{Results}

\section{Questionnaire answered after each book}

When all the schools were considered together, the study showed that 788 books were finished by the 83 pupils, meaning an average of 9.5 finished books per pupil. 160 books, or $17 \%$ of the books, were not finished. The most common reason given was because the text was "too boring".

The mean number of finished books per pupil was 9.6 among boys and 9.4 among girls. However, the number of finished books varied considerably between the schools among both boys (6-12) and girls (7-14). The school with the highest ranking in national tests (school 3) also had the highest number of finished books per pupil.

$50 \%$ of the responses rated the books as good, against $39 \%$ as fairly good and $11 \%$ as bad The girls were significantly more positive compared to boys with $55 \%$ of their responses rating the books good, against $44 \%$ of the boys' responses $(p<0.001)$. There was a significant difference between the schools in 
the evaluation of finished books $(\mathrm{p}<0.001)$ with the highest score for "good" ratings in school 3 (59\% good).

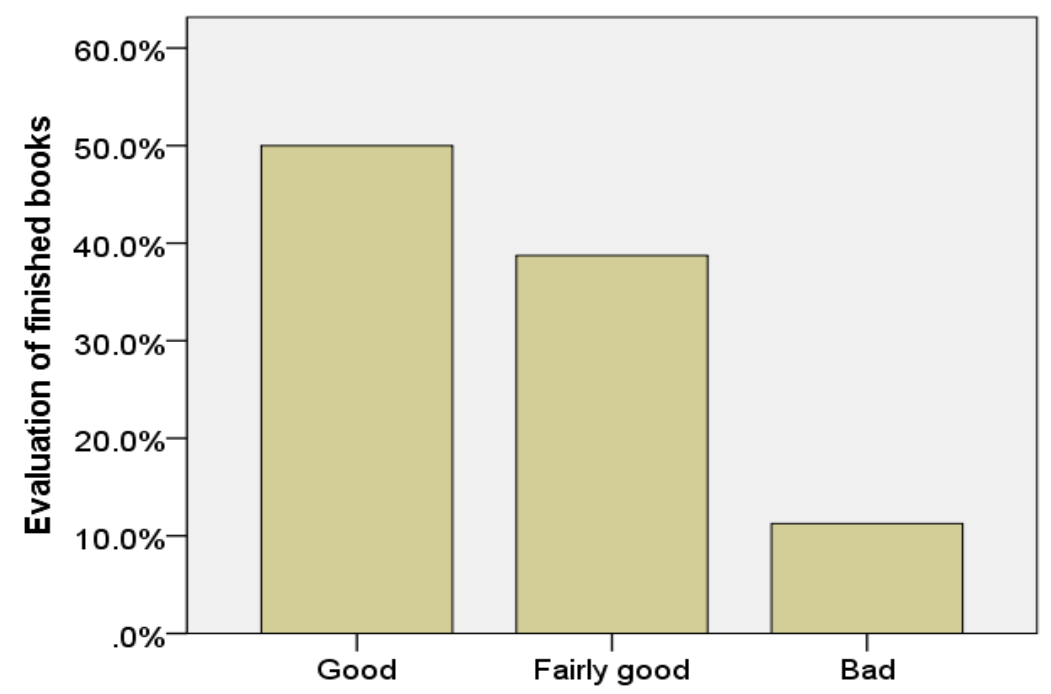

Figure 1. Pupils' evaluation of finished books, all three schools taken together

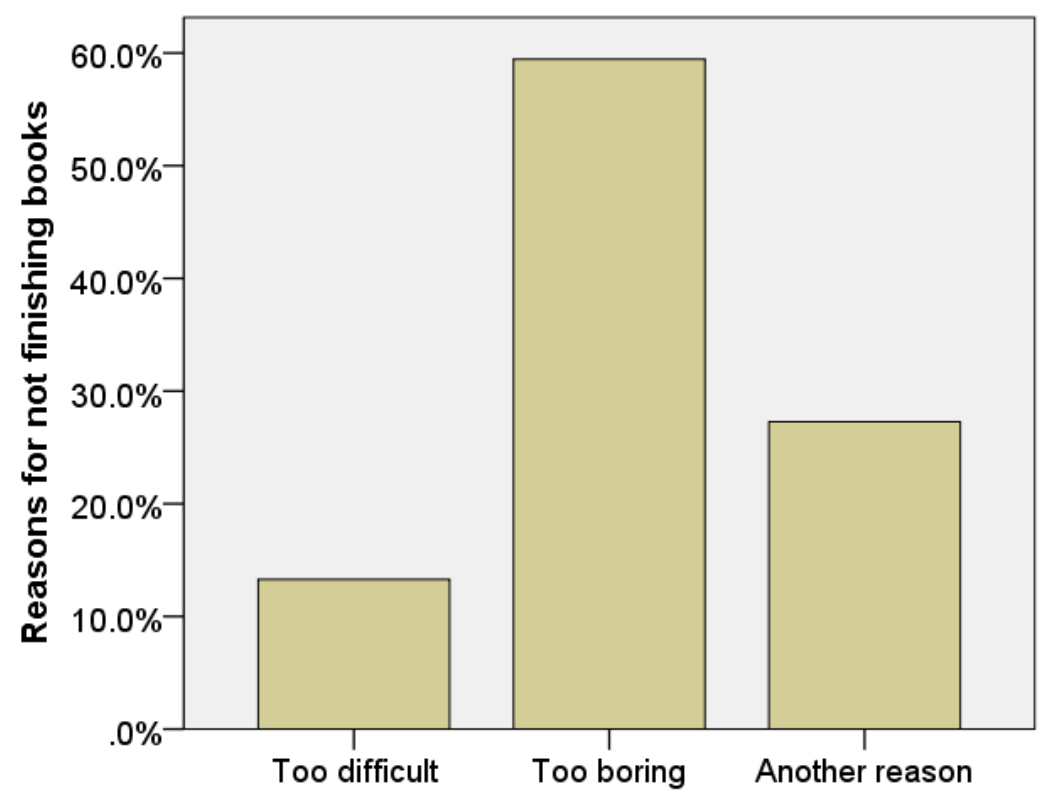

Figure 2. Pupils' reasons for not finishing books, all three schools taken together

The mean number of unfinished books per pupil was 1.9 , with only a small difference between boys (1.8) and girls (2.0), and there was not a large difference between the groups, except for boys in school 3 with an average of 1.3 unfinished books. The reasons given for not finishing the books were: "too boring" (59\% of the questionnaires), "too difficult" (13\%), and "another reason" (28\%). There was a significant difference in reasons for not finishing the books between boys and girls $(p=0.02)$, but not between the schools $(p=0.17)$. The boys in School 2 gave "too boring" as a reason the highest number of times, with $78 \%$, compared to $74 \%$ and $50 \%$ respectively from the boys in schools 1 and 3. 
Table 2. Results of questionnaires answered during the reading, split by schools and gender

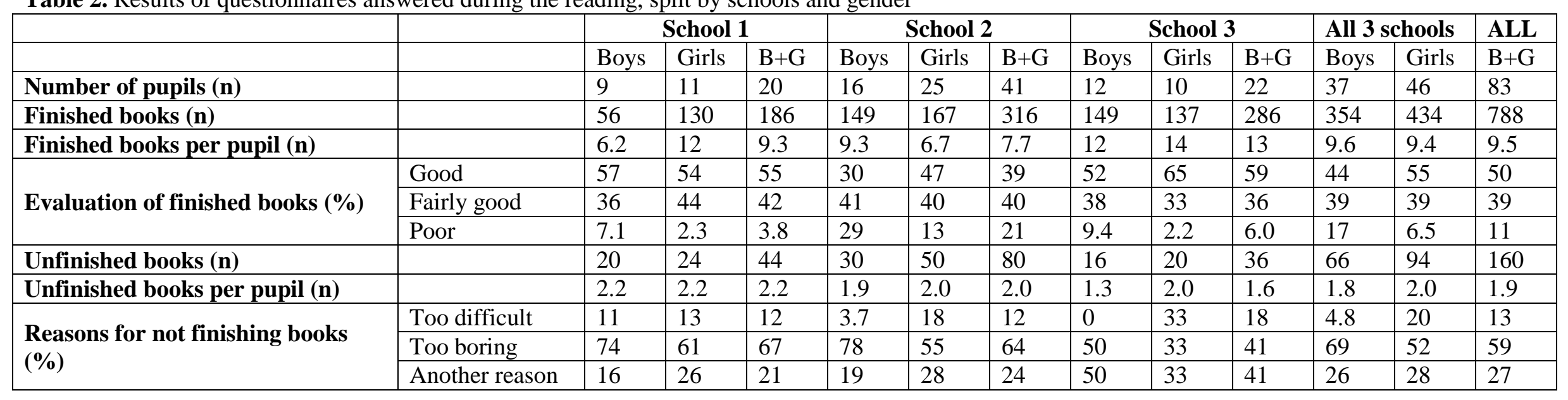


The girls (20\%) gave "too difficult" as a reason more often than the boys (4.8\%). The boys gave "too boring" as a reason more often than the girls (70\% against 52\%). Interestingly, in school 3 none of the boys gave "too difficult" as a reason. Also fewer of the boys gave "too boring" as a reason compared to the other schools.

Table 3 shows the most popular books in the study, and what type of books they were. The figures indicate the number of times the books were read. In the category All, comprising both boys and girls, the books that were read ten times or more are listed. For boys and girls separately, the ten most popular books are listed.

Table 3. The most popular books in the study

\begin{tabular}{|c|c|c|c|c|}
\hline Type of book & Title & $\begin{array}{l}\text { Boys } \\
\text { (times } \\
\text { read) }\end{array}$ & $\begin{array}{l}\text { Girls } \\
\text { (times } \\
\text { read) }\end{array}$ & $\begin{array}{l}\text { All (boys } \\
+ \text { girls) } \\
\text { (times } \\
\text { read) }\end{array}$ \\
\hline \multirow{4}{*}{$\begin{array}{l}\text { Picture book } \\
\text { humorous }\end{array}$} & Cole (1996) [1986]. Princess Smartypants & & 15 & 20 \\
\hline & Monks (2004). Aaaarrgghh, Spider!! & 6 & 6 & 12 \\
\hline & Wormell (2003). George and the Dragon & 8 & & 11 \\
\hline & Browne (2000). My dad & & & 10 \\
\hline Comic superhero & Hill (2009). Spider-man Versus the Vulture & 11 & & 13 \\
\hline \multirow{2}{*}{$\begin{array}{l}\text { Superhero } \\
\text { adventure }\end{array}$} & Gillen (2012). Young Avengers. Style- Substance & 12 & & 12 \\
\hline & Kane (2003). Batman: The Dynamic Duo & 6 & & \\
\hline $\begin{array}{l}\text { Fairy tale with a } \\
\text { twist }\end{array}$ & $\begin{array}{l}\text { Trivizas \& Oxenbury (1993). The Three Little } \\
\text { Wolves and the Big Bad Pig }\end{array}$ & 8 & 4 & 12 \\
\hline Fairy tale & Southgate (nd.) The Big Pancake & & 8 & 11 \\
\hline Science fiction & $\begin{array}{l}\text { Kotzwinkle (2002). E.T. The Extra-Terrestrial. } \\
\text { The Book of the Green Planet }\end{array}$ & 9 & & 11 \\
\hline $\begin{array}{l}\text { Picture book } \\
\text { fantasy }\end{array}$ & $\begin{array}{l}\text { Bartram (2002). Man on the Moon (a day in the } \\
\text { life of Bob }\end{array}$ & 6 & & 10 \\
\hline $\begin{array}{l}\text { Picture book, } \\
\text { friendship }\end{array}$ & Browne (2008) [1991]. Willy and Hugh & & 5 & \\
\hline \multirow[t]{2}{*}{ Animal story } & Vindalen (1993). Bert the Beaver & & 9 & 12 \\
\hline & Vindalen (1993). Ossy the Ostrich & & & 11 \\
\hline Real life story & Driscoll (2012). Titanic: The Story Lives On! & & & 11 \\
\hline Ghost story & Escott (2001). The Ghost House & 6 & & \\
\hline Comics & Cleary and Olivier (1996). Gu's World & 6 & & \\
\hline Funny story & $\begin{array}{l}\text { Ahlberg and Ahlberg (1980). Mrs Wobble the } \\
\text { Waitress }\end{array}$ & & 7 & \\
\hline Real event & Driscoll (2012) Titanic: The Story Lives On! & & 8 & 11 \\
\hline $\begin{array}{l}\text { Adapted text in } \\
\text { the Oxford } \\
\text { Reading Tree }\end{array}$ & $\begin{array}{l}\text { Hunt \& Brychta (2008) [1986]. Nobody wanted to } \\
\text { play }\end{array}$ & & 7 & \\
\hline Girls' story & Gail 1996 (1996). Flower Girl & & 7 & \\
\hline
\end{tabular}

The table shows that humorous picture books is a category popular with both genders in the study. However, Princess Smartypants, which was the most popular book in the study (read 20 times), was mostly read by girls (15 times). The boys read, for example, George and the Dragon (8 times). Both titles indicate the main character's gender. In contrast, a picture book such as Aaaarrgghh, 
Spider! can be said to have a gender neutral title, and seems to be favoured by the boys and girls alike. The Three Little Wolves and the Big Bad Pig is a humorous gender neutral fairy tale which seems to appeal to both genders. It is striking how the boys' and girls' choices of books seem to be related to their gender. Male choices seem to fall into the categories of superhero, adventure, science fiction and ghost stories whereas the female choices fall into the categories of traditional fairy tales (The Big Pancake), stories about friendship, animal stories, real events and traditional girls’ stories.

\section{Results from the questionnaire answered after finishing the project}

The first five questions primarily probed the pupils' attitudes toward reading. Questions 1 and 2 asked about the pupils' attitudes towards reading books in Norwegian (question 1) and English (question 2). To the statements I like to read books in Norwegian and I like to read books in English the results show that $87 \%$ "agree" or "agree strongly" to reading books in Norwegian. and the equivalent result of reading books in English is 70\%. Question 3 asks about the pupils' backgrounds in reading English books prior to the project. Almost $50 \%$ self-report that they read books in English before the project.

Question 4 asks whether they would like to continue reading English books in school. Almost $70 \%$ respond that they "agree" or "agree strongly" to this question. "Disagree" is 23\% and 8\% "disagree strongly". Question 5 asks whether they would like to continue reading English books at home and 50\% answer "agree" or "agree strongly" to this question. In question 7 the statement reads "I find it easier to read English now", to which 85\% "agree" or "agree strongly".

Pupils' positive disposition towards reading is the main idea in questions 6 and 8. Almost 80\% (78\%) think reading books in English has been a positive experience and $97 \%$ enjoyed being able to choose which books to read themselves.

The selection of books is an important aspect in developing potential motivation for reading (Day \& Bamford, 1998) and questions 8-10 and 13 seek to address the issue of material. 97\% enjoyed being able to choose books themselves. 53\% found it easy to select books. 25\% would have liked having more help in choosing books, whereas 75\% would not want any help. Question 13 allowed several answers.

The socio-cultural aspect of the reading experience at school is also an important factor. As questions 12 and 13 show, 70\% of the pupils recommended books to their classmates.

Figure 3 shows that the pupils' own assertiveness is more of a factor in their choices than help and guidance from others. The pupils checked the books themselves by looking at the front and/or back page (77\%) and/or by reading a few pages (50\%), as the pupils were encouraged to do. A strong motivation for selecting books was by recommendation from a classmate (54\%), rather than 
suggestions from the teacher or researchers. The category "Other reasons" was not investigated in an open question. Interestingly, the illustrations in books were not apparently relevant as this box was ticked by only just over a quarter of the pupils.

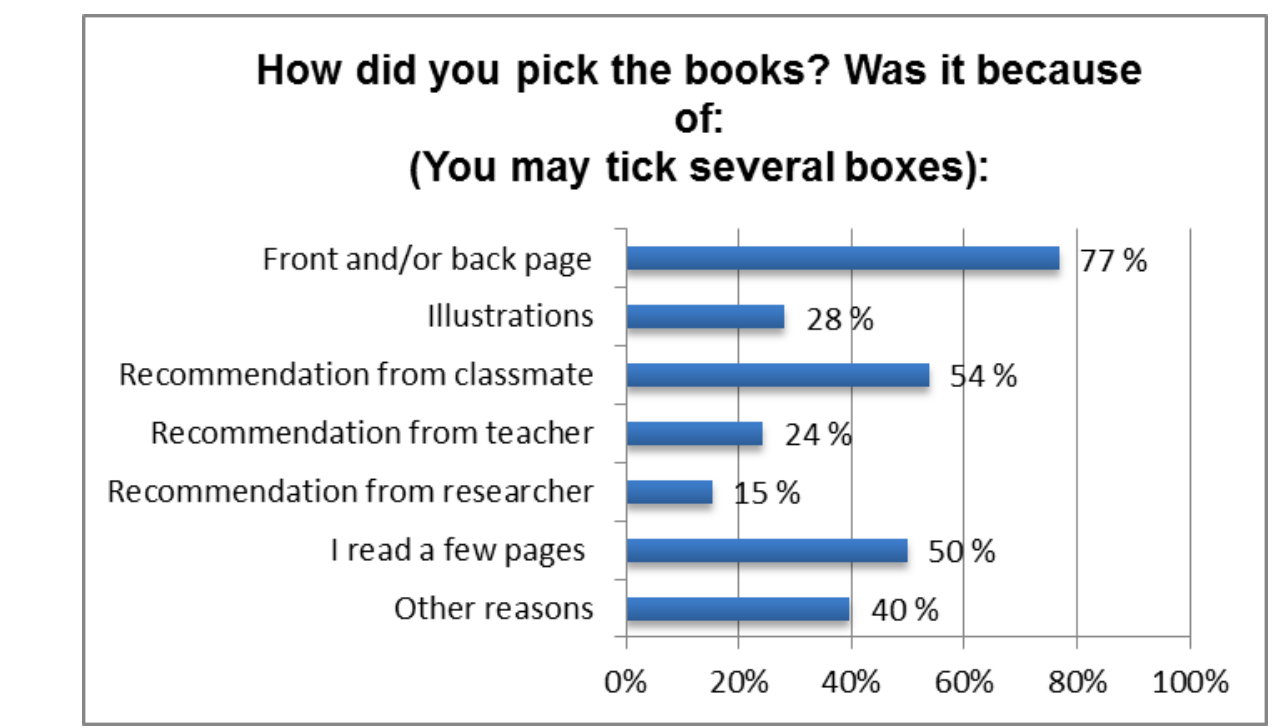

Figure 3. Pupils' answers to question 13: "How did you pick the books?"

\section{Discussion}

\section{The pupils' attitudes towards ER}

The fact that pupils averaged 9.5 books read over the course of the project indicates that the level at which the books were pitched was correct. It also indicates that the pupils were able to employ a range of reading strategies, whether cognitive or metacognitive, which allowed them to access the meaning of the texts. However, as we did not set activities that allowed us to check comprehension, as this would have been out of keeping with the ER approach adopted, we have no evidence of the full extent of their comprehension.

However, some further evidence supporting the view that pupils were understanding enough of what they read for meaningful comprehension of the story, can be found in the results for pupils' enjoyment of ER. Nearly four out of five pupils agreed that reading books in English was a positive experience. Furthermore, when asked why they did not finish a book, only $13 \%$ of them said that they stopped when it was too difficult, whereas 59\% gave up when it became boring, suggesting that learners could employ strategies that allowed them to access the text. Finally, pupils' self-efficacy perceptions were high at the end of the project, with $85 \%$ agreeing that they found it easier to read English after the project than at the beginning.

This positive engagement with ER is likely to have a favourable impact on learners' motivation. The fact that almost $70 \%$ agreed they'd like to continue with ER supports this. In particular, the degree of autonomy offered in the 
choice of materials was very telling: nearly all pupils enjoyed being able to select their own reading material according to interest (97\%). What is interesting, is that while the pupils enjoyed choosing themselves, they did not necessarily find it easy to find books to read, or were not confident about finding books to read. This may have to do with the number of books available at their level, or suited to their interests. The pupils had about 70 books in each cycle to choose from and even though this sounds as if they had a great variety, it possibly shows that readers need a greater variety of books within each reading level and genre in order to have a real choice of material. Nevertheless, it is worth noting choice and autonomy as important for stimulating motivation (Dörnyei, 1998; Reeve, 2002; Reeve, Ryan, Deci, \& Jang, 2008).

\section{The role of gender in the evaluation of the material}

The significant differences in evaluation between boys and girls indicate that the selection of reading material should be considered from a gender perspective. As discussed, boys tended to have particular tastes and preferences, such as action, science fiction, cartoons and humor. Perhaps there were not enough books appealing to boys' tastes in the selection. The pupils who were the last in the group to select a book during a reading cycle, obviously had less choice than the first ones. If it was a book of some length, it might not be available for more than one pupil during each cycle.

It is interesting to compare these findings to the pupils' preferences of reading material as shown in Table 3 . It reveals that there was only a little overlap between the genders as to the most popular books. One such category was humorous picture books, which appealed to both boys and girls, but if the main character's gender was revealed in the title of the book (Princess Smartypants or George and the Dragon), there were clear gender preferences. The most popular choices of books among the boys in the study often had a male superhero in the title such as Spiderman, Batman, Young Avengers or Man on the Moon, and exciting books and science fiction seemed to appeal to the boys in the study by Roe (2013, pp. 26-27) who found boys' motivation to read very much dependent on the content of what they read. The girls chose animal stories, stories based on true events, such as Titanic, stories about friendship, such as Willy and Hugh, with two male characters in the title. However, the girls also chose a typical girls' story such as Flower Girl. This only partly ties in with the findings of Wagemaker et al. (1996) discussed in the introduction, which stated that boys performed better when the literary text had a male as the main character, and that gender did not seem to matter to the girls. It is clear from the study that the boys and the girls had different tastes in reading material suggesting that teachers need to provide enough books of all categories to give the pupils a proper choice of material.

Our findings are supported by Day and Bamford's (1998, p. 28) expectancyvalue model. The model states that the material and the readers' attitude are the 
strongest factors affecting the motivation to read, followed by the sociocultural environment and the learner's perceptions of his or her reading ability.

\section{The role of academic achievement in the evaluation of the material}

The difference between the schools was also significant. In School 1, where the children were likely to be working at the lowest level academically, based on the national tests in $5^{\text {th }}$ grade English, books were judged "good" in just over half the questionnaires, school 3 was the most positive with 58.5\% deemed "good". School 2 gave "good" to $38.8 \%$ of the books read. The category "fairly good" varied less with school 1 and 2 around 40\% against school 3 with 35.6\%. The category "poor" varied most between the schools from 3.8\% and 6\% to $20.7 \%$ for school 2. In school 2, we also found the group of boys who were most critical of the material. The material was deemed "poor" by the boys in over $29 \%$ of the questionnaires.

The highest number of books read per pupil was found in school 3 where the children were likely to be working at the highest level in English, based on the national tests in $5^{\text {th }}$ grade. Boys' and girls' performances were quite similar, with the boys also reading a lot (12.4 against 13.7 on average). School 3 was also the most positive to the reading material, suggesting high self-efficacy beliefs in relation to "reading ability", and therefore also higher motivation and enjoyment according to Day and Bamford's (1998) expectancy-value model.

However, it is interesting that school 1, with pupils at the lowest level in the national test in $5^{\text {th }}$ grade, responded so positively to the reading material. It shows that pleasure reading and a good story motivate pupils at all levels. As ER gives pupils the opportunity to choose the reading material themselves, the chances of the reader finding the right book increase. The readers did not always find it easy to select books, but they certainly enjoyed the opportunity of choosing for themselves. It might provide further evidence that it is not about reading competence, as measured by the national tests, but rather about finding suitable material and accessing it independently that allows a student to feel like an efficacious reader.

\section{Limitations}

The study does not focus on reading competence per se, for example, we did not seek to measure reading fluency. Reading fluency is defined as "the ability to read a text accurately, quickly and with expression ... [It] provides a bridge between word recognition and comprehension. When fluent readers read silently, they recognize words automatically" (Reading rockets). As books can be complex or simple, long or short, the number of books read is not necessarily a measure of reading competence; it takes a lot less time to read a picture book such as My Dad, for example, than a 150-page-long story such as The Illustrated 
Mum. Moreover, only the short books could be read many times, as a longer book is perhaps only read by one pupil during each cycle in the reading project. In Table 3, showing the most popular books, only short books are listed. However, all the pupils had had access to the same books by the end of the project, so the table shows the most popular short books in the study and gender preferences.

If the pupils had not finished the book, they were asked to state why, and three categories were possible: because it was "too difficult", "too boring" or "another reason". In hindsight, it would have been useful to allow the readers to tell us why they did not finish a book and to have had a fourth category saying "lack of time" as some texts were quite long and there was probably not enough time for some pupils to finish the books.

Another limitation relates to the questionnaire answered after the project, where the pupils had to answer some of the questions retrospectively. Ideally, we would have had a pre- and post-questionnaire, where we could have mapped any change in reading attitudes.

\section{Closing comments}

The results of the study indicate that ER in English is feasible with primary school pupils, who in this study were able to access and enjoy, on average, almost 10 books each over a 14-month period. Our findings suggest that pupils were able to employ strategies that allowed them to access the texts successfully, usually only giving up if they found the material boring. Whether the strategies they employed were cognitive, that is, automatic processes already in their reading repertoires, or whether they were explicit, for example through self-talk or trying out different metacognitive strategies, is unclear and not the aim of the research. It would however, make for an interesting follow-up study where, using think aloud protocols, for example, learners' progress through longer books is charted.

Successful ER requires a wide and varied selection of reading material to offer learners choice as to both content and linguistic complexity. The teacher needs to think carefully about gender and reading preferences and make sure there is something for everybody, including reluctant readers. Equally important is the fostering of a reading culture in the classes by having ER as part of the inschool and out-of-school reading. In an ER approach, some of the books can be seen as light reading, and not "educational" enough. However, it is vital that the selection engages and amuses young readers. Learners who really want to read is the starting point for successful reading programmes, and reading for pleasure is the best way to create lifelong readers and learners.

There is a need to upgrade school libraries especially in primary schools with new, exciting material in English. The visual genres (graphic novels, comics, 
cartoons, picture books, and richly illustrated books) give ample visual support to the verbal text, and should be available in English in the school libraries together with a wide variety of other English language books.

\section{Acknowledgement}

We express our gratitude to Professor Magne Bråtveit who assisted us with statistical analyses.

\section{About the authors}

Anna Birketveit works at the Western Norway University of Applied Sciences. Institutional affiliation: Department of Language, Literature, Mathematics and interpreting, Western Norway University of Applied Sciences, Postbox 7030, 5020 Bergen, Norway.

E-mail: anna.birketveit@hvl.no

Hege Emma Rimmereide works at the Western Norway University of Applied Sciences.

Institutional affiliation: Department of Language, Literature, Mathematics and interpreting, Western Norway University of Applied Sciences, Postbox 7030, 5020 Bergen, Norway.

E-mail: hege.emma.rimmereide@hvl.no

Monika Bader works at the Western Norway University of Applied Sciences. Institutional affiliation: Department of Language, Literature, Mathematics and interpreting, Western Norway University of Applied Sciences, Postbox 7030, 5020 Bergen, Norway.

E-mail: monika.bader@hvl.no

Linda Fisher works at the University of Cambridge.

Institutional affiliation: The Faculty of Education, University of Cambridge, 184 Hills Road, Cambridge, CB2 8PQ, UK.

E-mail: lgf20@cam.ac.uk

\section{References}

Al-Homoud, F., \& Schmitt, N. (2009). Extensive reading in a challenging environment: A comparison of extensive and intensive reading approaches in Saudi Arabia. Language Teaching Research, 13(4), 383-401. 
Bakken, A. S. (2017). Notions of EFL Reading in Norwegian Curricula, 1939-2013. Acta Didactica Norge, 11(2), Art. 1.

Bell, T. (2001). Extensive reading: Speed and comprehension. The reading matrix, 1(1). www.readingmatrix.com/articles/bell/

Birketveit, A., \& Rimmereide, H. E. (2012). Does reading stories enhance language learning? In A. Hasselgreen, I. Drew, \& B. Sørheim (Eds.), The Young Language Learner: Research-based insights into teaching and learning (pp. 37-50). Bergen: Fagbokforlaget.

Birketveit, A., \& Rimmereide, H. E. (2017). Using authentic picture books and illustrated books to improve L2 writing among 11-year-olds. The Language Learning Journal, 45(1), 100-116.

Birketveit, A., \& Williams, G. (2013). Literature for the English classroom: theory into practice. Bergen: Fagbokforlaget.

Brevik, L. M. (2016). The gaming outliers: Does out-of-school gaming improve boys' reading skills in English as a second language? In E. Elstad (Ed.), Educational technology and polycontextual bridging (pp. 39-61). Sense Publishers.

Brozo, W. G. (2006). Bridges to literacy for boys. Educational Leadership, 64(1), 71-74.

Charboneau, R. (2012). Approaches and practices relating to the teaching of EFL reading at the Norwegian primary level. In A. Hasselgreen, I. Drew, \& B. Sørheim (Eds.), The Young Language Learner: Research-based insights into teaching and learning (pp. 5170). Bergen: Fagbokforlaget.

Cho, K.-S., \& Krashen, S. D. (1994). Acquisition of vocabulary from the Sweet Valley Kids series: Adult ESL acquisition. Journal of Reading, 37(8), 662-667.

Cohen, A. D. (1998). Strategies in learning and using a second language. Harlow: Pearson Education Limited.

Day, R. R., \& Bamford, J. (1998). Extensive Reading in the Second Language Classroom. Cambridge University Press.

Drew, I., Oostdam, R., \& Van Toorenburg, H. (2007). Teachers' experiences and perceptions of primary EFL in Norway and the Netherlands: a comparative study. European Journal of Teacher Education, 30(3), 319-341.

Dörnyei, Z. (1998). Motivation in second and foreign language learning. Language teaching, 31(3), 117-135.

Egan, K. (1997). The educated mind: how cognitive tools shape our understanding. Chicago: University of Chicago Press.

Egelund, N. (2012). Northern Lights on PISA 2009 - focus on reading. Nordic Council of Ministries. TemaNord 2012:501. https://rafhladan.is/bitstream/handle/10802/7971/FULLTEXT01.pdf?sequence=1

Elley, W. B. (1991). Acquiring literacy in a second language: The effect of book-based programs. Language learning, 41(3), 375-411.

Elley, W. B., \& Mangubhai, F. (1983). The Impact of Reading on Second Language Learning. Reading Research Quarterly, 19(1), 53-67. doi: https://doi.org/10.2307/747337

European Commission (2012). EU high level group of experts on literacy. Final Report. http://ec.europa.eu/dgs/education_culture/repository/education/policy/school/doc/literacyreport_en.pdf

Gabrielsen, E. (2017). Klar framgang! Leseferdighet på 4. og 5. trinn i et femårsperspektiv. Universitetsforlaget. https://www.idunn.no/file/pdf/67034010/klar-framgang.pdf

Grabe, W. (1991). Current Developments in Second Language Reading Research. TESOL Quarterly, 25(3), 375-406. doi: https://doi.org/10.2307/3586977

Grabe, W. (2009). Reading in a Second Language: Moving from Theory to Practice. Cambridge University Press. 
Hafiz, F. M., \& Tudor, I. (1989). Extensive reading and the development of language skills. ELT journal, 43(1), 4-13.

Hellekjær, G. O. (2007). Reading: From a forgotten to a basic skill. Språk og språkundervisning, 2(2007), 23-26.

Hoel, T. (2008). Gutter og lesing - lesevaner, lesetips, nye medier [Boys and reading reading habits, reading suggestions, new media]. Nasjonalt senter for leseopplæring og leseforskning, Universitetet i Stavanger.

Janopoulos, M. (1986). The Relationship of Pleasure Reading and Second Language Writing Proficiency. TESOL Quarterly, 20(4), 763-768. doi: https://doi.org/10.2307/3586526

Kolb, A. (2013). Extensive reading of picturebooks in primary EFL. In J. Bland \& C. Lütge (Eds.), Children's Literature in Second Language Education (pp. 33-43). London: Bloomsbury Academic.

Krashen, S. D. (2004). The power of reading: Insights from the research. Portsmouth: Heinemann.

Kverndokken, K. (2013). Gutter og lesing [Boys and reading]. Bergen: Fagbokforlaget.

Munden, J. (2014). Engelsk på mellomtrinnet [English at grades 5-7]. Oslo: Gyldendal Akademisk.

Reeve, J. (2002). Self-determination theory applied to educational settings. In E. L. Deci \& R. M. Ryan (Eds.), Handbook of self-determination research (pp. 183-203). Rochester, NY: University of Rochester Press.

Reeve, J. (2005). Understanding Motivation and Emotion. Fort Worth: Harcourt Brace Jovanovich College Publishers.

Reeve, J., Ryan, R., Deci, E., \& Jang, H. (2008). Understanding and promoting autonomous self-regulation: A self-determination theory perspective. In D. H. Schunk \& B. J. Zimmerman (Eds.), Motivation and self-regulated learning: Theory, research, and applications (pp. 223-244). New York: Lawrence Erlbaum Associates.

Roe, A. (2013). Norske gutters resultater på nasjonale og internasjonale leseprøver [Norwegian boys' achievement on national and international reading tests]. In K. Kverndokken (Ed.), Gutter og lesing [Boys and reading] (pp. 13-33). Bergen: Fagbokforlaget.

UDIR (2013). Utdanningsspeilet 2013. Oslo: Norwegian Directorate for Education and Training. Retrieved from https://www.udir.no/globalassets/filer/tall-ogforskning/rapporter/utdanningsspeilet_2013/us2013.pdf

Wagemaker, H., Taube, K., Munck, I., Kontogiannopoulou-Polydorides, G., \& Martin, M. (1996). Are girls better readers? Gender differences in reading literacy in 32 countries. Amsterdam: International Association for the Evaluation of Educational Achievement.

\section{Appendix}

\section{Primary texts}

Ahlberg, A., \& Ahlberg, J. (1980). Mrs wobble the waitress. London: Penguin Books. Austin, L. (2008). Robin Hood. Harlow: Penguin.

Bartram, S. (2002). Man on the moon (a day in the life of Bob). Dorking: Templar Publishing. Browne, A. (2000). My dad. London: Picture Corgi.

Browne, A. (2008 [1991]). Willy and Hugh. London: Picture Corgi.

Cleary, M., \& Olivier, J. (1996). Gu's world. Recanati: European Language Institute.

Cole, B. (1996 [1986]). Princess Smartypants. London: Puffin. 
Dahl, R. (2001 [1983]). The witches. London: Penguin.

Driscoll, L. (2012). Titanic: The story lives on! London: Penguin Books.

Escott, J. (2001). The ghost house. Harlow: Penguin Young Readers.

Gerstein, M. (2003). The man who walked between the towers. New York: Roaring Brook Press.

Hill, S. (2009). Spider-man versus the Vulture. New York: Harper Collins.

Hunt, R., \& Brychta, A. (2008/1986). Nobody wanted to play. Oxford: Oxford UP.

Gail, H. (1996). Flower girl. Harlow: Penguin Books.

Gillen, K. (2012). Young Avengers. Style-Substance. New York: Marvel Worldwide.

Kane, B. (2003). Batman: The dynamic trio. New York: DC Comics.

Kinney, J. (2007). Diary of a wimpy kid. New York: Amulet Books.

Kotzwinkle, W. (2002). E.T. The extra-terrestrial. The book of the green planet. Harlow:

Penguin Young Readers.

Monks, L. (2004). Aaaarrgghh, Spider! London: Egmont Books.

Pichon, L. (2011). The brilliant world of Tom Gates. London: Scholastic.

Simon, F. (2000 [1997]). Horrid Henry's nits. London: Orion Children's Books.

Southgate, V. (nd.) The Big Pancake. Loughborough: Ladybird Books.

Trivizas, E., \& Oxenbury, H. (1995 [1993]). The three little wolves and the big bad pig.

London: Mammoth Reed International Books.

Vindalen, A. (1993). Bert the beaver. Oslo: Cappelen.

Vindalen, A. (1993). Ossy the ostrich. Oslo: Cappelen.

Walliams, D. (2012). Ratburger. London: Harper Collins.

Wilson, J. [1999] (2000). The illustrated mum. London: Corgi.

Wormell, C. (2003). George and the Dragon. London: Red Fox.

Usborne Young Reading Series:

Davidson, S., \& Bursi, S. (Ill.) (2011). Pride and prejudice. Adapt. of Jane Austen's novel. Jones, R. L., \& Marks, A. (Ill.) (2008). Robin Hood.

Levene, R., \& Tavares, V. (Ill.) (2009). The three musketeers. Based on the novel by

Alexandre Dumas.

Punter, R., \& Mazali, G. (Ill.) (2013). Spartacus.

Sebag-Montefiore, M., \& Marks, A. (Ill.) (2010). Wuthering heights. Based on the story by Emily Brontë.

Wilkes, A., \& Dennis, P. (Ill.) (2006). The Adventures of King Arthur.

Wilkes, A., \& Dennis, P. (Ill.) (2007). Robinson Crusoe. Based on the story of Daniel Defoe. 